had no effect on this uptake. This supports the finding ${ }^{3,4}$ that $A D P$, but not DPN, is required by the sulphite-oxidizing system.

Department of Cell Biology,

John Innes Institute,

Bayfordbury,

Hertford, Herts.

IStickland, R. G., Biochem. J., 77, 636 (1960).

Birt, L. M. and Bartley, W., Biochem. J., "75, 303 (1960).

srrigoni, O., G. Biochim., 8, 180 (1959).

'Tager, J. M., and Rautanen, N., Biochim. biophys. Acta, 18, 111 (1955)

\section{Growth of Fomes annosus under Reduced Oxygen Pressure and the Effect of Carbon Dioxide}

Arthough most fungi are regarded as strictly aerobic organisms, some species-under natural conditions-are known to colonize in localities which $a$ priori must be expected to offer only poor supplies of free oxygen. This is the case with fungi attacking the interior of roots and stems of living trees. Owing to respiration in the living tissues of these organs, free oxygen dissolved in the water of vessels in sapwood and heartwood or present as free gas in intercellular spaces and non-functioning vessels is soon consumed. Concomitantly carbon dioxide is liberated. Diffusion of gases within a tree trunk probably occurs by the shortest distance, namely, by horizontal diffusion from the outside through the cortex into the interior of the stem and vice versa. However, in warm seasons when respiration-rate is high the very active cambium enclosing the central wood of a stem offers a barrier to the diffusion of gases in either direction ${ }^{1}$. Consequently as oxygen is consumed by living cells (medullary ray cells, parenchyma cells) in the sapwood the oxygen pressure will drop rapidly in the interior and be kept at a low level until diffusion is again made possible by a decrease in temperature.

Seasonal variation in oxygen and carbon dioxide pressures in stems of several hardwood and softwood trees has been investigated by Chase ${ }^{2}$, who found that in summer the oxygen content in the wood of Pinus strobus would drop to approximately 1 per cent, corresponding to a pressure of $8 \mathrm{~mm}$. mercury. At the same time the carbon dioxide content increased to approximately 10 per cent.

The parasitic basidiomycete Fomes annosus (Fr.) Cke. is known to attack roots and heartwood of many conifers and even deciduous trees, thus being exposed periodically to conditions of low oxygen pressure and high carbon dioxide pressure. It was, therefore, of interest to investigate the growth response of this fungus to such conditions.

Round 6-mm. pieces from the periphery of a young colony of $F$. annosus on malt agar were inoculated on to the surface of freshly boiled and poured malt agar in Petri dishes and incubated at room temperature in Brewer jars containing air, hydrogen, nitrogen and/or carbon dioxide. In the hydrogen jars all free oxygen and oxygen dissolved in the agar was removed by catalytic reaction with the hydrogen, the jars thus representing a strict anaerobic environment. No growth occurred in these jars (Table 1). In the nitrogen jars the oxygen was removed by three subsequent evacuations to $40 \mathrm{~mm}$. mercury and slow refillings with nitrogen which had passed through a wash bottle containing alcalic pyrogallol. Theoretically the nitrogen jars contained only $0.02 \mathrm{~mm}$. oxygen
Table 1. Growth of Fomes annosus on MALT AGAR IN AIR, NITroGEN, HYDROGEN AND CARBON DIOXIDE. TOTAL PRESSURE 760 MM Merdory. IncUbation 6 DAYs AT RoOM TEMPERATURE

$$
\underset{Q_{2}}{\operatorname{Gas}} \underset{\mathrm{N}_{2}}{\mathrm{H}_{3}} \underset{\mathrm{CO}}{\mathrm{Co}} \quad \underset{\text { growth }}{\text { Linear }}
$$

$\begin{array}{rrrlrl}160 & 600 & 0 & 0 \cdot 228 & 30 & \text { Atmospheric air } \\ 155 & 582 & 0 & 23 & 44 & \text { Carbon dioxide added to air } \\ 0 & \text { trace } & 760 & (\text { trace }) & 0 & \\ 0 & \text { trace } & 737 & 23 & 0 & \\ \text { trace } & 760 & 0 & \text { (trace) } & 30 & \\ \text { trace } & 737 & 0 & 23 & 45 & \end{array}$

although the actual content might have been somewhat higher because of sluggishness in oxygen diffusion from the agar. Nevertheless, these bottles repre. sented a micro-aerophilic environment in which $F$. annosus proved to grow unaffected.

For growth in pure carbon dioxide the jars were filled in the same way as with nitrogen except that the washing in pyrogallol was omitted. These jars also represented a micro-aerophilic milieu. With $760 \mathrm{~mm}$. carbon dioxide no growth occurred whereas $23 \mathrm{~mm}$. of the gas in combination with air or nitrogen accelerated growth about 50 per cent. As could be expected, no effect was obtained under strictly anaerobic conditions in hydrogen.

That neither hydrogen nor carbon dioxide in high concentration per se was toxic to $F$. annosus was shown by subsequent aerobic incubation at which normal growth was resumed.

Nine different strains of $F$. annosus (isolated from fruiting bodies on infected Pinus sylvestris and Picea abies) have responded qualitatively equal to these conditions. It could be concluded that $F^{\prime}$. annosus is a fungus able to grow equally well under aerobic as under microaerophilic conditions, but not anaerobically, and that a slight elevation of the carbon dioxide pressure has a stimulatory effect, but a high concentration of this gas an inhibitory effect on mycelial growth. These observations seem to agree well with what was to be expected from a fungus parasitizing the interior of roots and trunks.

Botanical Institute,

\section{K. Gundersen}

University of Gothenburg, Gothenburg.

${ }^{1}$ Goodwin, R. H., and Goddard, D. R., Amer. J. Bot., 27, 234 (1940). 'Chase, W. W., Minnesota Agric. Exp. Sta. T'ech. Bull., 99 (1934).

\section{Filtration of Phytoplankton by the Octocoral Alcyonium digitatum L.}

Most of the work carried out on the food and feeding of coelenterates deals with the true reefbuilding corals, Actiniae and Seyphomedusae, which harbour zooxanthellae in their tissues. The group Alcyonaria, however, has received less attention. There seems to be considerable controversy as concerns the significance of these symbiotic algae for their host-cœlenterates. Some authors report that the colenterates derive no benefit from their zooxanthellae ${ }^{1,2}$, while others believe that zooxanthellae form a considerable part of their food, the other part being of animal origin ${ }^{3-5}$. Still others maintain that some colenterates, namely the xeniid octocorals, may in some way or other rely on their algae as their only source of food ${ }^{6,7}$.

Little work has so far been done to study the food and feeding of alcyonarians which do not harbour zooxanthellae in their tissues, for example, Alcyonium digitatum L. ${ }^{8,8}$, which has beon described as carniv- 